\title{
From the Grand Duchy of Lithuania to the Belarusian Democratic Republic: the Idea of Belarusian Statehood during the German Occupation of Belarusian Lands, 1915 - 1919
}

\author{
BY \\ DOROTA MICHALUK AND PER ANDERS RUDLING*
}

During the first decades of the 20th century Belarusian national identity was in its infancy. Nationalist agitation was confined to a small elite. The political situation reflected a condition of widespread poverty and economic underdevelopment. The Russian imperial government left a legacy of a low level of education, few schools, and widespread illiteracy. ${ }^{1}$ Early national activists, such as the circle around the journal Naša Niva (1906-1915) argued for the use of the Belarusian language in all aspects of life. In 1907 it editorialises:

now it is possible to nurture the hope that our darkened (ciomny) Belarusian will wake up from his sleep and recognise that he is a human being. Perhaps one day we will even be able to hear the great words of science in our native language (Naša Niva 1907).

Belarusian nationalist pioneers referred to nationally unconscious Belarusian peasants as ciomny narod (literally: darkened people), and perceived themselves as enlighteners who would bring the light of education and modernity to awaken

\footnotetext{
* Dr hab. Dorota Michaluk is an Associate Professor in the Department of Eastern Europe at Nicolaus Copernicus University in Torun, Poland. Per Anders Rudling is an Associate Professor in the Department of History at Lund University, Sweden. While co-written, the introduction, sections on the biežanstva, Ober Ost and the conclusions are written primarily by Per Anders Rudling. The sections on the ideology, politics and internal divisions of Belarusian nationalism and the politics of the BNR are written primarily by Dorota Michaluk.

1 According to the census of 1897,70 per cent of the children above the age of 10 were illiterate in the European part of Russia. According to S. Snapkoŭskaja, in the lands which today constitute Belarus, only 25.7 per cent could read and write. According to the Polish census of 1931, in Poland as a whole the illiteracy rate was 31.1 per cent, whereas in the eastern Kresy (Polesie, Lwów, Stanisławów, Wilno, Wołyń, and Nowogródek voivodeships) it was 41 per cent amongst the entire multiethnic population (of Belarusians, Poles, Jews, and Ukrainians) above the age of 10; 17 per cent in the age group between 10 and 14, 31 per cent of those between the ages of 15 to 31 (CAW, Oddział II Sztabu Generalnego WP, 1. 303.4.5054; Drugi Powszechny Spis Ludności z 9 grudnia 1931 roku). On the literacy among the inhabitants of the Belarusian lands, see Snapkoŭskaja 1998, 12; Ulashchik, 1968; Tereshkovich 2004. The literature also contains examples of higher numbers. For instance, N. Niamiha claims an illiteracy rate of 71.1 per cent among the Western Belarusian population in 1931, a claim which should be treated with care, as we do not know the knowledge of what language he took into consideration: Polish or Belarusian (Niamiha 1956, 90).
} 
national and class consciousness in the peasants (Lindner 1999, 259). ${ }^{2}$ Social and political mobilisation is dependent on literacy, a public sphere, and communications, all of which were rare commodities in Belarus at the turn of the 20th century.

In his comparative study of nationalist movements Miroslav Hroch refers to Belarus at the turn of the previous century as one of the least developed areas in Europe. Describing the Belarusians as being in a 'medieval condition of national inertia', in Hroch's three-stage model of development of nationalist movements, the Belarusian lands still remained in their first stage, which he called phase A, signified by a heightened awareness among the intellectual elite (Hroch 2000, 184). Successful movements, Hroch maintained, would have to go through what he described as phase $\mathrm{B}$, the introduction of nationalism as a political project and accompanied by patriotic agitation. Phase C, according to Hroch, constituted the mobilisation of the masses into a mass political movement, with a chance of realizing the nationalist programme (Hroch 2000, 23).

This article is a study of the development of Belarusian nationalism during the German occupation of the Belarusian lands between 1915-1919, particularly the political developments in the western Belarusian lands under German occupation. Reorganised as the so-called land of Ober Ost, Western Belarus experienced an extended period of German control, starting in 1915, and lasting until the defeat of the Central Powers. What was the impact of the breakout of war and massive dislocation of people beginning in 1915? What were the German policies in the occupied Belarusian lands and did these facilitate national mobilisation? What were the aims and ambitions of nationalist activists, and why did they fail to establish a viable state in 1918 whereas Lithuanians succeeded? Those questions are at the forefront of this paper.

\section{Belarusian Nationalism on the Eve of World War I}

At the time of the outbreak of World War I Belarusian nationalism remained weak. The leading Belarusian party was the Belarusian Socialist Hramada (BSH), a party established in 1903 (it received its name in 1906), as a successor of the Belarusian Revolutionary Party (1902) and the Belarusian Revolutionary Hramada (1903). The most important issue in its program was 'the peasant question,' which was of particular importance in the largely pre-industrial Belarusian lands, with unequal land distribution between the peasantry and the landed gentry. As far as

\footnotetext{
After 1905, the nationally conscious elite was dismayed by the low level of social and political awareness, a result of which was the Belarusian peasantry's rejection of the revolutionary movement and their support for the authorities and right-wing, monarchist parties during the elections to the Second Duma in 1906. On the election and political movements in the Belarusian lands, see Bich 2005, 327-331. The framing of consciousness and ignorance as a juxtaposition between light and darkness is found also in the Ukrainian nationalist movement (Heretz 2007).
} 
the 'question of statehood' was concerned, most supported the establishment of a federal, democratic Russian republic, which would give Belarusians the right of national self-determination. It was not until 1906, at the Second Congress of the $\mathrm{BSH}$, that its members formulated demands to abolish autocracy in Russia and create an autonomous region made up of Belarus and Lithuania. An entity which would roughly correspond to the territory of the former Great Duchy of Lithuania (GDL), known as 'historical Lithuania'. Members also wished to convene a national diet to deal with the pre-partition of the capital city, known in Belarusian as Viĺnia, Lithuanian as Vilnius, and Polish as Wilno (Snyder 2003, 31-57).

Following the incorporation of the lands of the GDL into Russia at the end of the 18th century, two concepts of regional identities developed in the Belarusian lands. One was a territorial nationalism based upon a shared historical attachment to the lands of the Polish-Lithuanian Commonwealth, against which stood an opposing tradition, which perceived the Belarusians as the western branch of the Russian people. These traditions became known as territorial ideology (ideologia krajowa) and west-Ruthenism (zapadnorusizm). Both influenced the development of the Belarusian national idea.

The first assumed the equality of all original inhabitants of historic Lithuania, which, at the turn of the last century was administratively part of the Northwestern region (Severo-zapadnyi krai) of the Russian Empire (Smaliančuk 2004, 369; Szpoper 1999; Jurkiewicz 1983). It regarded Poles, Lithuanians, Belarusians and usually Jews (but not Russians) as the region's historical nations. Krajowy thought was based upon the idea of territorial nationalism, and developed out of the traditions of the Polish-Lithuanian Commonwealth (the union of the GDL with the Crown of the Kingdom of Poland). It took into consideration the ethnic and cultural heterogeneity of the lands of the GDL, and also the fact that many people lacked a neatly defined national consciousness. It recognised that they were simultaneously Poles, Lithuanians, and Belarusians, and proposed a joint identity based upon their joint 700-year heritage of the union with Lithuania. Many early Belarusian nationalists linked this idea to democratic values, rejected the idea of loyalty to the tsar and demanded an end to autocracy. This democratic current was particularly strong in Viĺnia in the early 1900s. At the turn of the century Jews, Poles and Belarusians constituted the city's three largest ethnic groups. The Lithuanians, which today dominate the city, constituted only the fourth largest ethnic group.

'West-Ruthenism,' or zapadnorusizm, also became an element of the Belarusian national idea. It can be regarded as part of the krajowy tradition, except that the West-Ruthenian tradition oriented itself in the opposite direction (Ćvikievič 1993 [1929], 7; Latyszonek 1999, 36). It appealed to the Orthodox heritage and the tradition of Kievan Rus'- Ruthenia, and negated links with Catholic Poland. 
Excluding the Poles, this tradition assumed that Orthodox Belarusians (White Ruthenians), Ukrainians (Little Ruthenians), and Russians (Great Ruthenians/ Great Russians) formed the three branches of the 'tri-singular' Russian nation. After the 1863 uprising, the imperial authorities came to promote a version of West-Ruthenism as a counterweight to Polish nationalism. This tradition came to have a significant influence on Belarusian nationalism as it developed a modern concept of nationality.

\section{The National Question in the Belarusian Lands during World War I}

The outbreak of World War I brought forced 'nationalisation' upon the peoples who populated the borderlands of the Russian Empire. National differences were highlighted, national minorities were increasingly branded as 'aliens' and outsiders. An imperial decree of 2 February 1915 established a 16,000 kilometer long border region along the western frontier of the Russian Empire from Norway to Persia. This forced farmers in ethnic German settlements and Austrian's, Hungarian's and German subjects to register and sell their properties (Lohr 2003, 101). Popular resentment towards Germany and Germans was strong. Public conversations in German were banned, and from 1915 many Germans were deported eastwards (Sushko 2002, 34). The number of German and other colonists was limited in the Belarusian lands. ${ }^{3}$ The war brought about radicalisation of some members of the population and a new political atmosphere. Latvian and Jewish refugees, who often had German surnames were often mistaken for Germans and faced hatred, suspicion, and discrimination (Gatrell 1999, 149 and 159; Strazhas 1993).

During the period between 1915 and 1918 the eastern and western parts of Belarus developed relatively differently. In the west, the German authorities encouraged the formation of national consciousness, something the nationalist elite tried to utilise to their advantage. In the east, on the other hand, the authorities conducted extensive Russian nationalising propaganda. The mass propaganda on both sides of the front highlighted ethnic and religious differences in a region where ethnic identities were still a recent and relatively unfamiliar concept.

\section{The Great Exodus of Belarusians in 1915}

Shortly after the outbreak of war, in the fall of 1914 the imperial authorities initiated a campaign to evacuate parts of the population in case of a German invasion (Karnialiuk 1999, 24). The planned evacuation turned chaotic as the war effort proved unsuccessful and the front drew closer. Taking orders from above,

3 According to the Cracow statistical association there 15,278 Protestant believers in Hrodna gubernia, and 1,674 in Białystok poviat (Karnialiuk 1999, 25). 
and guided by a strong Russian anti-German nationalism, the Orthodox clergy perceived the conflict as a patriotic war in which it had a duty to prevent resources and people from falling into enemy hands (Karnaliuk 1999, 28).

From August 1915 the tsarist authorities embarked on an unprecedented propaganda campaign in the borderlands, disseminating rumours about horrendous German atrocities. According to the priests, German soldiers cut the breasts off women, the noses and ears off children, blinded men and killed many people without discrimination (Mironowicz 2000, 6). The authorities soon learned that it was easier and more effective to demonise and instil fear of the enemy than mobilise the masses through the use of new, and still-unfamiliar concepts of nationalism (Hahn 1995).

In order to facilitate the evacuation of the borderlands cossacks were sent to the villages, spreading fear among the population by disseminating rumours about imminent death at the hands of the Germans. ${ }^{4}$ Memories differed from village to village: 'people came from the Polish villages and told us what the Germans were doing: beating people and raping women. The next day our entire village moved; no one forced us to escape', an eyewitness remembered. ${ }^{5}$ In some villages they physically expelled the residents. One of the refugees later recalled:

I remember that autumn-like day in August of 1915. An entire squadron of Cossacks entered our village. They divided themselves up on the farmsteads and forced all of us out of the houses, making us leave. ${ }^{6}$

Whereas entire villages and areas were emptied of their Orthodox population, there was a clear difference in how the Orthodox and Catholic clergy approached the situation. Belarusian national activist Aliaksandr Ćvikievič later wrote that, 'of misguided patriotism, and sometimes simply on orders from above, the Orthodox priests brought entire parishes into central Russia. ${ }^{7}$ The Catholic priests, on the contrary, used all their power to keep the people from leaving' (Karnaliuk 1999, 28). As Roman Catholic refugees were rare and the authorities did not encourage the Jewish population to leave, there was a change in demographics. ${ }^{8}$

\footnotetext{
4 'Tak budavalasia kamuna',1999 interview with eyewitness Anton Bartašuk, born 1906; 'Maci ne davialosia viarnucca,' 1909 interview with Piatro Hryharuk, born 1909 (Luba 2000, 43-44, 79).

5 'Muku ŭ vadu chavali', 2000 interview with Andrej Dambroŭski, born 1907 (Luba 2000, 84).

6 'Nialiohka zavodzilasia', 1977 interview with eyewitness Andrej Salavaniuk, born 1907 (Luba 2000, 292).

7 Aliaksandr Ćvikievič (1883-1937), graduate of the university of Dorpat, lawyer, feature writer, and national activist, was a founder of the Belarusian National Hramada and a delegate of the 1917 First All-Belarusian Congress. He was the representative of the government of the BNR to the Ukrainian Peoples' Republic (UNR) in 1918, and from 1923 Prime Minister of the BNR government in exile. After his return to Minsk Ćvikievič worked in Historical Institute of the BSSR Academy of Science BAS. He was arrested in 1929, exiled to Perm, and executed by the NKVD in 1937.

8 Read more in Luba (2000).
} 
More than 1.4 million people left Western Belarus, particularly Hrodna gubernia and Podlasie, the extreme western area of the Belarusian settlement. Many refugees were evacuated deep into what today is the Russian Federation. In May 1918, as the German army advanced further east, nearly 2.3 million people left Belarus, 2,060,000 of whom were Belarusians and Russians (Mironowicz 2000, 8; Łatyszonek 1995, 35). During the summer of 1915 Viciebsk, Minsk, Mahilioŭ were 'crowded to the limit', and turned into feeding stations. An estimated 250,000 people crowded the roads between Brest-Litoŭsk, Sluck and Minsk. 200,000 refugees passed through Viciebsk (Gatrell 1999, 21). Many emptied villages were burnt to the ground.

This demographic change significantly lowered the concentration of Belarusians in the western part of their historical lands of settlement, something that had an adverse impact on the development of Belarusian nationalism as many were absent during the crucial year 1918 (Mironowicz 2000, 8). Belarusian Catholics who remained in the area were cut off from the rest of the community and were receptive to Polish nationalist agitation (Latyszonek 1995, 37). Only a small elite developed a Belarusian consciousness, something the local Polish elite in the Viĺnia/Wilno/Vilnius area used to its advantage. Wanting to claim the Vilinia area for a Polish state, they manipulated the 1916 census by significantly reducing the number of Belarusians (Sukiennicki 1984, 161).

\section{The German 'Discovery' of Belarus}

The conditions for those who stayed behind were quite different than the picture the tsarist authorities presented. The German occupation was mild and the authorities relatively tolerant, even supportive of local cultures in the occupied eastern territories.

If the Belarusian population had very limited knowledge of the German invaders and their plans for the occupied territories, the German troops likewise knew little about the land into which they arrived. German soldiers who fought in Baranavičy in the summer of 1916 describe the unfamiliar landscape as uncomfortable and treacherous:

Trench warfare at the Oginsky canal, at the Shchara and Siarvech' trench warfare in swamps, sand dunes, and forests! North of Pinsk, in the middle of the marches and swamps lies the watershed between the Black and Baltic Seas. The brown water of the Dnester, Wistula and Neman moves slowly. Thousands of rivulets, unregulated rivers, frequent floods change the landscape for extended periods of time. Bogs mix with marshlands, forest with swamps and meadow, sand 
dunes with meagre arable land. Rotting tree trunks shimmer secretively in the night over a swaying cover of plants. Reeds surround inscrutable water-filled holes. Deciduous forests nestle into the dune ranges on the riverbanks of the Shchara and Servets rivers. The swampland of the Oginski canal is an area of low intensity warfare. The primal forests between Ligoshchin, the Oginski Lake and the Shchara river bend is hardly conducive to the movement of regular units. The peaty soil trembles and heaves. The sagging footbridges are held up by logs. The enemy can use the wide, barren spaces in the marchlands to seek refuge when under fire. Thick undergrowth, numerous water veins and black ponds make the movements difficult at every turn. Posts, patrols, and recognisance men become pray to a death in the swamps and marches. Mercilessly the deceptive undergrowth sucks its victims into the brown, gurgling depth. Resourcefulness, agility and presence of mind are prerequisite for the warfare of the patrols and hunting commandos in these insidious areas. It is so much easier for the Russians! Scattered inhabitants, familiar with the secrets of this swamp landscape, come to their aid (Vogel 1926, 13).

If the landscape appeared mysterious, so did its inhabitants. The German authorities operated within a national paradigm and were puzzled by what they discovered in the occupied territory they called land of Ober Ost. Here they encountered a people who largely lacked the national consciousness they had expected. Erich Ludendorff, Chief of the German General Staff was surprised to learn of the 'discovery' of a 'new', mysterious people in the middle of Europe:

'at first, they were literally not to be found. Only later was it revealed that they were an extremely diffused, but superficially Polonised tribe, standing on such a low level of Kultur that it can only be helped by a sustained period of influence'.

Ludendorff wrote in his memoirs, blaming the Poles for this state of affairs:

'Poles had taken the nationality from [the Belarusian] without giving him anything in return' (Ludendorff 1919, 145).

The local population interchangeably described themselves as Lithuanians, Poles, Catholics, locals, Orthodox, and Russians. The German administration struggled to find an adequate term to describe this newly 'discovered' people, using terms as Stamm, Völkerstamm, or Völkerschaft, roughly translated as tribe, tribal nation, or nation-in-the-making (Liulevicius 2000, 122). Ludendorff saw this as a political opportunity and implemented massive measures to consolidate and support the es- 
tablishment of Belarusian culture as a counterweight to Polish nationalism, which he perceived as a political liability. In order to achieve this objective, Ludendorff needed a better understanding of these people under German rule. Attempts to organise a census failed, as the overwhelming majority of Belarusians were illiterate and unfamiliar with modern concepts of 'race' and 'ethnicity', building blocks for modern European states and something German administrators took for granted. The locals surprised the German authorities by their seemingly inconsistent and overlapping identities. German officials were puzzled by the fact that the locals did not identify themselves by language, and were shocked to learn that in some cases they were even unable to ascertain what language was spoken at home (Liulevicius 2000, 120-121). Partially, this was a result of the 1915 biežanstva. A significant part of the Orthodox population had been evacuated to Russia, so the people surveyed by the German authorities were primarily Roman Catholics with a hybrid language and identity (Michaluk 2010, 132-133; Łatyszonek 1995, 34). ${ }^{9}$

The German administration largely treated the Belarusians with benevolent patronisation, in accordance with centrally issued orders that all 'people-tribes of the area under command are to be treated by all German officers on equal terms' (Liulevicius 2000, 122; Łatyszonek 1995, 38). In an attempt to alleviate the 'primitiveness' of the Belarusians, the German authorities implemented measures to promote Kultur and bring about a Belarusian renaissance by the use of mass education, publication of a local Belarusian-language newspaper, and the establishment and staging of Belarusian plays (Liulevicius 2000, 121 and 138-139). Rather than a forced Germanisation of these lands, the German authorities supported local cultures and national movements. They not only abolished anti-Semitic laws and extended civil rights to Jews, who constituted the majority or plurality in most of the cities in the land of Ober Ost, but they also recognised Jewish organisations and supported Yiddish language schools and papers. The German administration even introduced multi-lingual passports, the first ones ever issued in Belarusian and Yiddish (Dos amolike Varshe 1966, 844; Katz 2004, 279). On 13 November 1915 the first Belarusian school was opened in the land of Ober Ost. Whereas initiatives to the first schools came from Belarusian activists without any support from the German authorities, the authorities did not try to prevent their establishment (Liachoŭski 2010, 119 and 129). Soon the German authorities came to see the benefit of the schools, which came to figure in their planning.

On 22 December 1916 Paul von Hindenburg banned instruction in the Russian language in the land of Ober Ost. Religion and science were to be taught in the

\footnotetext{
9 The German knowledge of Belarusian culture, traditions, and language significantly increased during the three years of occupation, partly due to people like Juliana Maenke, an ethnic German from the Wilno area and the fiancée of Ivan Luckievič, a member of the Belarusian Committee in Wilno. Maenke worked as a translator for Walter Jäger, an officer of the German tenth army and editor of the tenth' army's paper Armee-Zeitung (Jäger 1919).
} 
native languages, other subjects in German. By October 1916 eight Belarusian language schools, 260 Lithuanian, and 385 Polish language schools were operating. This number grew rapidly. In December 1917 the number of Belarusian schools grew to 15, Lithuanian to 542, whereas Polish had declined to 291. In April, 1918 there were 89 Belarusian schools, 710 Lithuanian, and 299 Polish. The number of pupils, educated in the Belarusian language increased from 641 at the end of 1916 to 3,266 in 1917 (Turonek 1993, 20-21; Michaluk 2010, 137). The Polish language press both locally and abroad was highly critical of the Belarusisation of education, and condemned it as 'a purely German intrigue' (Liachoŭski 2010, 127). The impact of the suppression of the Russian language and treatment of Belarusian as equal to Polish and Lithuanian should not be underestimated. The Belarusisation of the education system, intended as a counterweight against Polonisation was utilised to expand a political consciousness among the peasantry. The development of national education and culture were necessary steps for the construction of a Belarusian nation, in turn a requirement for political independence (Liachoŭski 2010, 129).

\section{The Luckievič Brothers and the State Project}

From the time of the 1905 revolution, Viĺnia became an important centre for Belarusian culture. The city was home to several members of the Belarusian intelligentsia, even though the 8,000 Belarusians constituted no more than $4.2 \%$ of the city's population (Eberhardt 2003, 199-202).

While political activism was technically forbidden in the land of Ober Ost, a political umbrella organisation, called the Belarusian National Committee was organised in Viĺnia in 1915, as a coordinating organ for Belarusian organisations. Led by national activist Anton Luckievič, it included predominantly socialist national movements. The brothers Anton and Ivan Luckievič (1884-1942 and 1881-1919) came to play leading roles in the Belarusian National Committee, working from 1915 to 1917 for the re-establishment of the Grand Duchy of Lithuania in the form of a confederation of the historical Lithuanian and Belarusian lands (Eatyszonek 1995, 39). Following the breakout of war, the Luckievič brothers, adherents of the tradition, tried to continue their cooperation with representatives of other national groups in the territory.

One of their attempts to promote the position was the Universal Act of the Confederation of the Grand Duchy of Lithuania, signed by the Provisional Council of the Confederation in February 1916 (Michaluk 2010, 140-141). The Council was created to establish an independent political organism, a revived form of the Grand Duchy of Lithuania in the Belarusian and Lithuanian lands occupied by the 
German army (Karp 1994, 414). The Luckievič brothers supposed that if Germany and Austro-Hungary were victorious in the war, the Polish, Belarusian-Lithuanian and Baltic lands would be detached from Russia and form either a number of disparate political units, or a single political entity negotiated in some form with the victorious Central Powers. Partly, the Luckievič brothers articulated their agenda in accordance with the German concept of Mitteleuropa, the outlines of which had been presented by the Lutheran minister and liberal politician Friedrich Naumann, who envisioned a post-war German cultural and economic empire in central and Eastern Europe (Naumann 1915). However, the Luckievičes' initiative failed as it received little support from the elites among the intended partner nationalities. In 1916, the Luckievičes then proposed a different project, again based upon the idea of a reconstructed Grand Duchy of Lithuania: the creation of a league of united states from the Baltic Sea to the Black Sea, a federation that was to include Belarus, Lithuania, Latvia and Ukraine (Sukienniecki 1984, 232-39; Luckievič 1990, 6-7).

\section{The 'National Conception'}

The year of 1917 saw the emergence of a rival idea to the plans to reconstitute the GDL, the so-called 'national conception,' the project to integrate the ethnic Belarusian lands on both sides of the German-Russian front into one political unit. This concept was advanced by Vaclaŭ Lastoŭski, ${ }^{10}$ Vincent Śviatopolk-Mirski, ${ }^{11}$ and Kazimierz Shafnagel, ${ }^{12}$ members of the Union for Independence and the Indivisibility of Belarus (Suviaź niezaliežnaści i niepadzieĺnaści Bielarusi, SNNB), active in Viĺnia between 1916 and 1918 (Sidarevič 2001, 439). ${ }^{13}$ Nevertheless, at a Belarusian conference organised in Viĺnia in January 1917, the concept had to yield to an alternative project: the creation of a joint Lithuanian-Belarusian state made up of two autonomous territories, each vested with equal powers. One com-

10 Vaclaŭ Lastoŭski (1883-1938), feature writer, historian, member of the Polish Socialist Party (1902), Belarusian Socialist Hramada (1906-1908), Christian Union (1915), Belarusian Social-Revolutionary Party (1919). Studies at St Petersburg University (1904-1905); editor of Naša Niva (1909-1914) and Homan (1916-1917); Prime Minister of the BNR government in exile from late 1918. After returning to Minsk in the 1920s he worked in the Historical Institute of the BSSR Academy of Sciences until his arrest in 1929. Exiled to Perm, executed by the NKVD in 1938.

11 Vincent Śviatopolk-Mirski, duke, member of an aristocratic family, and one of the members of the nobility which became an activist of Belarusian nationalism. Political and social activist, in 1915 member of the Belarusian Society for Assisting the Victims of War in Vilinia. The Belarusian member of the Lithuanian Taryba (1918-1919).

${ }^{12}$ Kazimierz Shafnagel (1858-1929), a graduate of the Faculty of Chemistry at the Riga Technical University (1880), member of Polish Society and the Circle of the Idealists, the founder of Polish Academic Corporation ('Arkonia') at the Riga Technical University; the owner of Kulszany in Vilno gubernia; supporter of the early Belarusian nationalism.

13 The entry author states 1917 as the year of founding, however, the Union existed already in April 1916. 
plication here (most likely under the influence of the SNNB) was that this intended Lithuanian-Belarusian state aspired to include all Belarusian lands - including those on the eastern side of the front. The result of the conference was the establishment of the Belarusian Council of Viĺnia (Vilenskaja Bielaruskaja Rada, VBR) under the leadership of Anton Luckievič. It was intended to represent Belarusians before the German authorities, and to coordinate Belarusian nationalist activism in territories under German occupation.

\section{Eastern Belarus after the February Revolution}

If Belarusian political and cultural activities were restricted by constraints imposed by occupying German authorities, the situation on the other side of the front was far harsher. Here, the Imperial Russian authorities converted the eastern and central parts of Belarus into a Russian fortified camp, in which all other nationalist activities, whether Polish, Belarusian or Ukrainian, were forbidden. During the first years of the war, the only venue for Belarusian national activism was the sole Belarusian organisation allowed to function - the Belarusian Society for the Aid of the Victims of War. The Society's chapters were active in a number of Russian cities.

Therefore, at least as far as Belarusian nationalism in the lands still under Imperial Russian control was concerned, it is difficult to accept that war and revolution were the primary causes leading to the growth and intensification of the Belarusian nationalist activism. Rather, the political situation in eastern Belarus inhibited national activism, while radicalising societal attitudes. This three-year decline of nationalist activities was broken by the February Revolution. Nevertheless, compared to the frantic activism among the national elites of neighbouring peoples, Belarusian nationalism consolidated at a very slow pace, failing to develop a broad social consensus. The news of the 1917 February Revolution led to the development of citizens' committees and councils made up of workers, soldiers and peasants' delegates across the Belarusian lands, while local government organs such as provincial and municipal government (duma) attempted to keep order. Of the 26 parties and political organisations active in Belarus from March to November 1917, between March to November 1917, 14 were Belarusian (Ladyseŭ and Bryhadzin 1999, 5).

Due to the relative weakness of elites, the Belarusian nationalists approached the question of statehood much more cautiously than did their neighbours. However, it is hard to resist the observation that Belarusian activists of this period judged their political chances accurately; promptly adjusting aspirations to capacity, and political situation. They reasoned that the most reasonable outcome 
was a federation with Russia. This, they argued, could be used as a platform to advance future claims for political autonomy. A convention of Belarusian nationalist organisations, in the spring of 1917, led to the founding of a Belarusian National Committee (Bielaruski nacyjanaíny kamitet, BNK), which was intended to coordinate Belarusian nationalist activities on the eastern side of the front (LCVA, f. 582, ap. 1, 1. 49 ff.). At its head stood Raman Skirmunt ${ }^{14}$ - a landowner, a deputy to the Duma, a nationalist equally at home in Polish and Belarusian cultures (Rudovič 1999, 20-32; Utgof 2004, 59).

Skirmunt sought to unify the Belarusian national organisations and develop a programme for the establishment of Belarusian statehood (Smaliančuk 1999, 114-15). The establishment of the BNK marked the moment when Minsk replaced Viĺnia as the most important centre of Belarusian political life. While the BNK was meant to stay in contact with the provisional government, in reality this was ignored. The leadership of the BNK failed to gain significant support, as Skirmunt failed to link his state project to social programmes. In particular, he failed to propose any radical land reforms, something the lower social strata had come to expect. Rather, his intention was to unite all inhabitants around the idea of Belarusian national statehood. As this plan also included the landed gentry, Belarusian socialists quickly came to accuse him of abetting Polish and Lithuanian interests, something which was soon followed by accusations of being pro-German (Turuk 1921, 33). In July 1917, Skirmunt was dismissed from his post and the BNK was disbanded. In its place the Congress of Belarusian Organisations and Parties (Zjezd bielaruskich arhanizacyj i partyj) was created (Rudovič 2001, 131).

The collapse of Russia, the breakdown of its military structures, the chaos in the aftermath of the Bolshevik seizure of power in October 1917, and the concerns that the Belarusian lands may become partitioned, convinced Belarusian activists that they had to act quickly, as there was very little time to decide Belarus' future. The significant presence of increasingly discontented soldiers made the Russian side of the front a hotbed of radical political activism. In the elections to the allRussian Constituent Assembly in November 1917, the Bolsheviks received 63.1 per cent of the votes in Belarus. Support for the Bolsheviks was particularly strong on the Belarusian front where they received 66.9 percent of the votes. On the other hand, nationalist parties, like the Belarusian Socialist Hramada only received marginal support with 0.3 per cent of the votes cast (Urban 1994, 51). That said, much of the support base for the Bolsheviks came from soldiers, most of whom were sent to the Belarusian front from other parts of Russia, and radicalised by the

\footnotetext{
${ }^{14}$ Raman Skirmunt (1868-1939), graduate of the University of Vienna, political and social activist of aristocratic Lithuanian family, deputy to the First Duma (1906), land owner in Poliessie, supporter of krajowy ideology and the Belarusian national movement, leader of Minsk Belarusian Representation (1918), Prime Minister of the BNR (1918), senator in the Polish Parliament, murdered in the fall of 1939.
} 
disastrous mismanagement of the war, or by national minorities. The Belarusians remained a peasant people, overwhelmingly rural, and with little or no contact with the Bolsheviks (Pipes 1997, 74-75).

On 18 December 1917, five hundred people gathered in Minsk for the First All-Belarusian Congress (LCVA, f. 582, ap. 1, b. 1, 1. 1, 8). ${ }^{15}$ Socially, this assembly claimed to represent the Belarusian middle class and wealthier peasants. Politically, most of its delegates represented the left wing of Belarusian nationalism. At this congress four different visions of the future political organisation of the Belarusian lands were articulated (Jezavitaŭ 1993, 25-29). One plan was to organise all Belarusian lands as one Russian province (voblaść). A second was the creation of an autonomous polity with its own administration. A third option was the declaration of a Belarusian Republic in close federation with Russia. A fourth and final option was, the complete merger of Belarus and Russia. Not a single delegate raised the possibility of Belarusian independence and breaking away from Russia.

\section{Brest-Litoŭsk and German Control in Central and Eastern Belarus}

The idea of state independence developed in response to its rapid development among neighbouring national elites. The successive proclamations of independence by Ukraine, Latvia and Lithuania hurried the decision to declare the Belarusian Democratic Republic (initially in federation with Russia). In particular, the decision by the Taryba, the Lithuanian Council, to opt for Lithuanian statehood within the ethnically Lithuanian lands completely shattered the Luckievič brothers' hopes of building a Lithuanian-Belarusian state. The Belarusian national activists were also influenced by the stance of Soviet Russian representatives. Soviet Russia objected to the nationalists' aspiration for an autonomous and independent state, and on 30 December 1917 the Bolsheviks dispersed the All-Belarusian Congress.

On 18 February 1918, following the breakdown of the negotiations between Germany and Soviet Russia, Germany resumed its offensive against Soviet Russia. The German eastward advance meant that both sides of Belarus (with the exception of the easternmost part), hitherto separated by the Russo-German front found themselves under a single occupation. For the first time since August 1915, contact between the inhabitants from both sides of Belarus became possible.

\footnotetext{
${ }^{15}$ While the protocols list 500 delegates, claims of 1,872 delegates having gathered for the First AllBelarusian Congress, figure in the literature. However, this claim is not backed up by sources; fitting 1,872 people in the Minsk city theatre would have been physically impossible. Compare ('Protokol No. 1. Chastnago soveshchaniia chlenov Vsebelorusskago S'ezda v gorodskom teatre 5-go dekabria 1917-go goda v 8 chasov vechera' (LCVA, f. 582, ap. 1, b. 1, 1.1 and 'Protokol No. 14. Ot 8-go dekabria. Zasedanie otkryvaetsia v 12 chasov 20 minut dnia'(LCVA, f. 582, ap. 1, b. 1, 1. 8), and Chigrinov $(2004,450)$.
} 
As the Bolsheviks departed, the Executive Committee of the All-Belarusian Congress re-emerged from underground. The first government, aspiring to speak in the name of the Belarusian people was the People's Secretariat of Belarus, headed by Jazep Varonka. ${ }^{16}$ However, at the First Constitutional Convention (also known as the First Constitutional Hramata), the resolutions of which were published on 21 February 1918, mentioned neither national independence nor Belarusian autonomy (NARB, f. 582, op. 2, sp. 12, 1. 3; Šupa 1998, 46-47). On 25 February the Germans took control of Minsk. The failure to declare independence in the first Constitutional Manifesto turned out to be a fatal error. However, given the chaotic situation with the German forces approaching the city, such a declaration would have been exceedingly difficult. Furthermore, it might have opened the People's Secretariat to accusations of treason by the Minsk pro-Russian organisations, and would even make it impossible for the People's Secretariat to function. On the other hand, the appearance of another organ aspiring to govern Belarus, and one that had persistently stressed its links to Russia, may have raised German suspicions that this was all part of their enemies' agenda. At any rate, the Germans, at least in the beginning, were convinced of this and did not recognise the Belarusian government. Only after some days had passed did the Germans and Belarusian activists come to an understanding.

On 3 March 1918, Soviet Russia signed a peace treaty with Germany and its allies. The territories, claimed by the Belarusian government were partitioned. The north-eastern part and Podlasie fell to Germany, which was to decide the future destiny of these territories. The central and eastern parts of Belarus, all the way beyond the Dnepr River, were to be handed back to Soviet Russia, but only after reparations had been paid. For the time being the Bolsheviks retained the Smolensk region and parts of Mahilioŭ and Viciebsk regions. Palessie/ Polissia was to be incorporated into the Ukrainian People's Republic (Michaluk 2007, 248). Germany committed itself not to recognise any other states which might desire to proclaim independence in the territory of the former Russian Empire after 3 March 1918 Peace Treaty was signed. These nationalists' aspirations to statehood and determined the next move of the Belarusian political elite. On 9 March 1918, they put forth the Second Constitutional Convention (or Second Constitutional Hramata) proclaiming the establishment of the Belarusian

\footnotetext{
16 Jazep Varonka (1891-1952), Belarusian politician, journalist, feature writer. Student at the Faculty of Law at the University in Petersburg (before 1914), member of Belarusian Society for Assisting the Victims of War in Petrograd (1917), member of the First All-Belarusian Congress in Minsk (1917), first Prime Minister of the BNR (1918), Minister of Belarusian Affairs in the government of Lithuania (1918-1920, president of Belarusian Hramada in Kaunas (1922). Emigrated to the US in 1923.
} 
Democratic Republic (Bielaruskaja Narodnaja Respublika, BNR) ${ }^{17}$ (NARB, f. 582, op. 2 , sp. 2, 1. 2a-b).

On 23 March a delegation of the Belarusian Council of Viĺnia, headed by the Luckievič brothers, arrived to Minsk, strengthening the supporters of independence. On 25 March1918, the Independence Act (also known as the Third Constitutional Convention or the Third Constitutional Hramata) was accepted by a majority of votes. A declaration of intent was issued to sever ties with Russia. The declaration stated that the Belarusian Democratic Republic ought to take possession of all lands 'where the Belarusian nation dwells and constitutes the majority of the inhabitants: the Mahilioŭ region, parts of Minsk, Hrodna (including the cities of Hrodna and Białystok), Viĺnia, Viciebsk, Smolensk, Čarnihioŭ regions, and the borderlands of neighbouring provinces inhabited by Belarusians' (Šupa 1998, 62-63). Executive powers were to be exercised by the Council of the BNR until the convening of a legislative diet.

The members of the former Council of the First All-Belarusian Congress and the Belarusian Council of Viĺnia (VBR) unanimously acclaimed the Independence Act, whereas the representatives of the Russian Socialist-Revolutionary Party and the Mensheviks were opposed. Jewish parties, such as the Bundists and Poale Zion, but also the Belarusian Socialist Revolutionaries abstained from voting (Törnquist-Plewa 2001, 56). Under the influence of the latter, the representatives of the provincial and municipal assemblies in the Minsk province also voted against the Act (Herasimava 2000,32). At the news of the Independence Act, the German authorities dispersed the Council and the People's Secretariat of the BNR. It took several days for relations to stabilise enough for the German occupying authorities to recognise the Council of the BNR as the national representative body. However, the People's Secretariat was allowed only to administer national education, culture and social welfare. Throughout its occupation of Belarusian lands, Germany remained loyal to its treaty with Soviet Russia and did not officially recognise Belarusian independence. Germany also refused the establishment of Belarusian military formations, even when faced with direct threats from Belarusian lands by the Red Army.

Immediately after the 25 March 1918 Independence Act it became apparent that the Varonka government and the Council of the Republic faced not only external challenges, but also domestic opposition. As long as it was declared that the BNR would be bound to Russia on a federative basis, the initiatives of the Belarusian national activists could find support amongst Russian sympathisers. The emphatic attempt to separate from Russia provoked a backlash and a withdrawal of support for the Republican Council and the People's Secretariat. The declaration

\footnotetext{
${ }^{17}$ In English, the Belarusian Democratic Republic is often referred to as the Belarusian People's Republic, or Belarusian National Republic. Here, we have used the Belarusian abbreviation, BNR. On Stalin, proto-states and the early use of the term 'People's Republic', see Graziosi (2009).
} 
of Belarusian independence also caused a reaction from some Polish circles in Belarus. The Polish Council of the Minsk Region sent Jazep Varonka documents which listed the conditions under which it would agree to join the Council of the BNR (Šupa 1998, 72). It assured the Belarusians that it supported independence yet emphasised that the support of western states and an alliance with Poland were necessary conditions for Belarusian statehood (Tarasiuk 2001, 186-93; Smaliančuk 2001, 171-85). This stood in complete opposition to the project of a federation with Russia and the pro-Russian faction.

The establishment of regional structures and the organisation of a network of BNR councils appears to have been carried out with the approval of the German authorities. However, one should emphasise that the German authorities accepted the People's Secretariat and the Council of the BNR only as bodies representing the Belarusian people and not as organs with political powers. While the territories claimed for the BNR were relatively extensive, the situation in the spring of 1918 was quite different. The People's Secretariat could only operate in the small territory of Belarusian lands, which were under the jurisdiction of the German High Command of the Eastern Front.

In March 1918, Jazep Varonka's government issued a decree that it was taking over authority of 'all governance institutions in Belarus' (Šupa 1998, 66). In practice, the People's Secretariat only managed to take patronage over Belarusian cultural and educational institutions - many of which it had founded. Without financial support the Peoples Secretariat's activities were limited focusing mainly on getting control over assets disposed of by municipal and territorial local governments, who tended to be dominated by people of a pro-Russian orientation. After the announcement of the Second Constitutional Convention (Second Constitutional Hramata), on 9 March 1918, Minsk provincial and municipal governments and Jewish self-governance organs provided financial support for the organisational structures of the BNR, while the Bychaŭ municipal government in the Mahilioŭ gubernia also promised support. Given these circumstances, the advance payment of 300,000 roubles from the Ukrainian People's Republic's Ministry of Trade in May 1918 for the sale of wood to Ukraine was a much-needed addition to their funds (Šupa 1998, 148 and 196).

Varonka needed to be especially careful when dealing with Germany. The relationship with the German occupational administration was dictated by the political situation. The years of the German presence in Lithuania and Belarus had established a foundation for German-Belarusian cooperation. However, if the relations between Belarusian activists and the German authorities in Vilinia and Hrodna were good, in the parts of central Belarus, conquered in February 1918 , the attitudes of the inhabitants to the Germans varied from suspicious to downright hostile. The population's sympathies remained with Russia, and few 
could imagine the detachment of Belarus from the Russian state. The Bolsheviks attempted to take advantage of the chaos evoked by the collapse of the monarchy and the general feeling of confusion amongst the population. The populist slogans of the Bolsheviks often found an audience among the population, which had long wanted changes of the social and political system. Many people saw in Lenin's government a continuation of the Russian state. Others counted on the Whites to defeat the Bolsheviks and opposed the severing of ties with Russia. The Rada's attempts to obtain German support for Belarusian independence led to sharp criticism and accusations of treason.

When the Council of the BNR proclaimed state independence it also declared void the provisions of the Treaty of Brest-Litoŭsk. The People's Secretariat informed the German government about the founding of the BNR and demanded the treaty to be revised. But the German Chancellor Georg von Hertling announced that Berlin considered Belarus to be a part of Soviet Russia and that in accordance with the treaty of Brest-Litoŭsk, recognition of its independence required the consent of Lenin's government (Varonka 1920, 11). The German military authorities in the occupied Belarusian territories pursued a somewhat different policy, allowing the People's Secretariat of the BNR to represent the Belarusian people. By tolerating organised Belarusian nationalism the German military hoped to prevent the growth of resentment, which could have fuelled pro-Bolshevik sympathies.

For their part, the People's Secretariat of the BNR tried to win Berlin over for the Belarusian cause. On 5 April 1918 Varonka sent von Hartling an extensive memorandum detailing the history of the Belarusian people and its nationalist movement, as well as presenting him with the BNR's recent declaration of statehood (Šupa 1998, 79-85). A similar memoriam was handed to the German Ambassador in Kyiv, A. Mumma von Schwartzenstein by members of the Extraordinary Delegation of the BNR: Aliaksandr Ćvikievič, Mitrofan Doŭnar-Zapoĺski and Pietr Trempovič.

However, the German military government of the land of Ober Ost was anxious that the revolutionary atmosphere might ignite Belarus and looked for more moderate partners than the Varonka government, which consisted exclusively of radical socialists. Fearful that the Germans might dissolve the People's Secretariat and the Council of the BNR, Varonka invited the members of the Skirmunt-led Minsk Belarusian Representation (Mienskaje bielaruskaje pradstaŭnictva, MBP) into the BNR's governing structures, as most of the members of the MBP were Catholics from the upper social strata, and held moderate political views. Orthodox members of the Council of the BNR tended to view the MBP as Polish-orientated and interested in maintaining the status quo when it came to the social question. 
Given the popular hostility against Germany, particularly in the eastern part of Belarus, which had been subjected to years of anti-German propaganda, the BNR activists' attempts to enlist support was a risky strategy. It is in line with this strategy that the BNR leadership sent a telegram to Emperor Wilhelm II thanking him for liberating Belarus from Russian rule and asking for support and an alliance with Germany (Šupa 1998, 129-30). Sending the telegram was the nail in the coffin for the Varonka cabinet. Left-wing Belarusian activists, pro-Russian and anti-German members of municipal and territorial councils reacted vehemently to the telegram, revealing a significant distrust against the policies of the People's Secretariat. Raman Skirmunt was held personally responsible for the decision to send the telegram, even though the decision had been made by a wider group. The crisis not only brought down the Varonka cabinet, it led to a rift in the Belarusian nationalist intelligentsia at a time when unity around the notion of statehood was of paramount importance. The BSH split into three parties: the Belarusian SocialistRevolutionary Party, the Belarusian Socialist-Democratic Party and the Belarusian Socialist-Federative Party.

\section{The Consolidation of Lithuania}

In comparison to their Belarusian counterparts, Lithuanian elites were more successful. On 23 March 1918, two days before the declaration of Belarusian statehood, Berlin recognised the independence of Lithuania and transferred to its jurisdiction parts of the land of Ober Ost all the way to the Ukrainian border including lands mostly inhabited by Belarusians. The Lithuanian government sought support for Lithuanian statehood among the population of the Viĺnia and Hrodna regions, targeting, in particular, Belarusians living in Viĺnia. At the end of April 1918, members of the Belarusian Council of Viĺnia (VBR) Anton Luckievič, Daminik Siamaška ${ }^{18}$ and Adam Stankievič ${ }^{19}$ met in Viĺnia with the Taryba

\footnotetext{
18 Daminik Siamaška (1878-1932) Belarusian politician, supporter of the March 25 Declaration of Independence, member of Taryba as the representative of Belarusian Council of Viĺnia, member of the Lithuanian delegation to the Versailles Peace Conference in 1910. Siemaško supported the idea of joining the Viĺnia and Hrodna regions to Lithuania. He later became the Minister of Belarusian Affairs in the Lithuanian government in Kaunas.

19 Adam Stankievič (1891-1949) editor, historian, journalist, graduate of the Roman Catholic seminary in Petrograd (1918), Roman Catholic priest (from 1914), leader and founder of Christian Democratic Union and Belarusian Christian Democracy. From 1919 teacher in Viĺnia Belarusian High School, editor of Krynica, depute to Polish Sejm (1922-1928), member of Belarusian Club of Parliament Deputies, arrested in 1944 and again in 1949 by the NKVD, sentenced into 25 years of prison, died in Irkutsk oblast'.
} 
members Jonas Vileišis, ${ }^{20}$ Steponas Kairys ${ }^{21}$ and Aleksandras Stulginskis. ${ }^{22}$ The latter tried to convince the VBR members to establish Belarusian representation in the Lithuanian Council. However, the Belarusians declared that their aim was the rebirth of the GDL in the form of a federation of the two states (Lithuania and Belarus), each within their ethnic boundaries, and therefore, much larger than what the Lithuanians envisaged (Gimžauskas 1999, 7). The representatives of the VBR presented the conditions for their cooperation. They required that the name 'the Council of Lithuania' (Lietuvos Taryba) be changed to 'the State Council,' and that the Council's membership based on the principle of proportional representation upon the basis of the population of all the lands claimed by Belarusian activists. Were these to be implemented, the number of Belarusian delegates in the Council would far outnumber the Lithuanians. Furthermore, the Belarusian delegates demanded that the Lithuanians support the maintenance of the integrity of Belarusian lands (including those in the hands of the Bolsheviks), rather than only pursue the annexation of the lands under the first German occupation (the Viĺnia and Hrodna regions). Finally, the VBR required that Lithuania agree to the federation of the two states, which would automatically force Lithuania to recognise the independence of the BNR. The Council of the BNR had no intention to renege on the question of Belarusian statehood (Michaluk 2010, 348-357).

The Lithuanian side could not accept the conditions of the VBR. It would have required them to violate the provisions of the German-Bolshevik agreement, and support the BNR Rada's aim to recover the territories of eastern and central Belarus, and the Bielsk and Białystok districts, something which would have led to conflict with its German protector. Therefore, the Lithuanian activists increasingly gave up on the krajowy ideology. They came to concentrate on the building of a state within the Lithuanian ethno-linguistic boundaries. This meant a much smaller state with narrow ethnic boundaries, based on the national sovereignty of Lithuanianspeakers. The fact that the Taryba laid claim to the Viĺnia and Hrodna regions - areas, where there were few Lithuanian-speakers, did not change their ethnolinguistic conceptualisation of Lithuanian statehood. Belarusians, who constituted the majority population in these territories, would therefore not be equal partners,

\footnotetext{
${ }^{20}$ Jonas Vileišis (1872-1942) journalist, politician, lawyer, before 1917 supporter of krajowy ideology, the representative of Lithuania in Berlin and Washington (1919), mayor of Kaunas (1921-1931).

${ }^{21}$ Steponas Kairys (1878-1964) activist of the Lithuanian Social-Democratic movement, member of the Second Duma. While an adherent of krajowy ideology Kairys supported the Lithuanian declaration of independence in 1918. Vice marshal of the Lithuanian Parliament (1926), leader of the Highest Committee of Liberation the Lithuania (1943). Emigrated in 1945 to Germany and from there to the US.

${ }^{22}$ Aleksandras Stulginskis (1885-1969) Lithuanian politician, graduate of the Agronomical Institute in Halle, the founder of Lithuania Christian Democratic Party (LKD), supporter of the Independence Act of Lithuania in 1918, president of Lithuania (1922-1926). Arrested by NKVD in 1941, exiled to Siberia 1952-1956, returned to Kaunas in 1956, where he died.
} 
but a national minority. Ironically, the Lithuanian leadership needed Belarusians to join the Taryba exactly in the position of national minority to demonstrate its commitment to minority rights and democratic standards in the emerging postwar order. This was something the Belarusian leaders could not accept. The lack of common objectives led to the breakdown of the negotiations. The Belarusian delegation left for Minsk where a new cabinet of the People's Secretariat was being formed.

\section{Why Did the BNR Fail to Consolidate?}

Jazep Varonka, the first Premier of the BNR failed to consolidate the Belarusian polity. His successors Raman Skirmunt and Ivan Sierada ${ }^{23}$ similarly lacked both the power and authority to do so (Michaluk 2010, 313-332). It got an authoritative leader only in October 1918, when Anton Luckievič was chosen to lead the cabinet. While the period of the first three People's Secretariats (March-October 1918) coincided with the expansion of the German occupation zone, Germany decided not to support the BNR's claim to independence. It kept the Council of the Republic at a distance, regarding them only as representatives of Belarusian nationals. They did not wish to break the 3 March 1918 agreement with the Bolsheviks. The BNR state structures in the Minsk, Viĺnia, and the Hrodna regions and Poliessie operated through Belarusian councils at the local level. Ukrainians, Lithuanians and Poles were active on the same territories. Each attempted to establish foundations for their own state organs, hoping to adjoin these territories to their respective national states. While it is difficult to ascertain whether Belarusian Commissioners (envoys of the BNR) were active in Bolshevik-controlled Mahilioŭ, Viciebsk and Smolensk provinces, these regions witnessed anti-Bolshevik demonstrations.

The first three BNR governments all shared a strategy to seek recognition of their state and find a political protector and ally. Varonka's government aimed at establishing a Ukrainian-Belarusian alliance, a logical choice of allies as Ukraine and Belarus had similar experiences during the war and both governments were constituted by socialists. ${ }^{24}$ Like the Council and People's Secretariat of the BNR, the Central Rada and government of the Ukrainian People's Republic (Ukrains 'ka Narodna Respublika, UNR) were largely made up of ideologically kindred socialists who pursued similar political and social aims. The BNR leadership continued to sue for support from the new government established under Pavlo Skoropads'kyi.

\footnotetext{
${ }^{23}$ Ivan Sierada (1879 - after 1943) Belarusian politician, feature writer, graduate of Warsaw Veterinary Institute (1903), member of the Belarusian Socialist Hramada, Prime Minister of the BNR (1918). Moved to the BSSR in the 1920s, where he became the director and organiser of a Veterinary High School. He was arrested on trumped up charges in 1930 as a member of the fictitious Union for the Liberation of Belarus, and exiled to Jaroslav for five years. In 1941 he was again sentenced to 10 years in the GULag. Nothing is known of his fate after 1943.

${ }^{24}$ For more on the collaboration between BRL and URL see Michaluk (2010, 303-12; 2004, 107-14).
} 
Kyiv formally recognised the BNR, exchanged diplomatic representatives and provided some financial support, but offered no concrete help to the fledging BNR. If Kyiv was unable or unwilling to offer formal support, the governments in Berlin, Vienna, and the Bolsheviks in Moscow offered even less, turning down the BNR's requests for recognition.

A serious mistake made by all three of the first BNR governments was that they did not put enough energy into trying to build a broad social consensus. Particularly troubling was its failure to include the part of the landed gentry which was sympathetic to the idea of Belarusian statehood. The Polish landowners gathered around the Polish Council of Minsk conditioning their support for the Belarusian project on an alliance with Poland (Tarasiuk 2001, 186). This turned out to be a weak and uncertain basis for an alliance, as Belarusian activists were radicalised and expressed an overt hostility towards the landed gentry and the Polish state. On their part, the 'Belarusian Poles' withdrew their support for the Belarusian project.

The attempts to consolidate the population of the Belarusian lands around a program of independence failed. One particular difficulty for Belarusian national activists was the religious heterogeneity of the community. Belarusian activists did not know how to, and often did not wish to, overcome the bipolarity that was a result of the Belarusians' religious divide. Some of the leading Orthodox Belarusian activists wanted an alliance with a democratic Russia (which was not an option at this time), while the Catholic minority oriented itself westwards, opting for an alliance with Poland. Orthodox aversion towards Poles was partly the effect of long-term Russian state policy, partly due to their close cultural links to Russia.

There was also a class aspect to this, as Poles tended to be associated with the land-owning nobility. Furthermore, many of the politically conscious Orthodox Belarusians found it hard to disassociate themselves from the Russian culture with which they were familiar and comfortable, and which had offered them social advancement. Polish culture was not only less familiar to them, but was also associated with class inequality and unable to inspire trust. A compromise between the two sides was impossible, not only due to differences in values, but also in conflicting visions of property relations. Given the dire circumstances and the BNR's failure to gain international recognition, the political divisions and factionalism within the Belarusian elite were not only reckless, but politically suicidal.

\section{The Collapse of the Central Powers}

In early November 1918, revolution broke out in Germany. On 9 November, Prince Maximilian of Baden announced the abdication of Emperor Wilhelm II 
and conveyed the chancellorship to the social democratic leader Friedrich Ebert. On 11 November, in a railway carriage in the Compiègne Forest in Rethondes, an armistice was signed. Simultaneously, in accordance with the 27 August 1918 Soviet - German agreement, the Bolsheviks started to take over the counties of Orša, Lepieí, Mahilioŭ, Polack and Senno.

Thus, it was under changed political circumstances that Anton Luckievič began forming a new cabinet. The activists of the Belarusian national movement held him in high esteem, as co-creator and leader the Belarusian national movement. The first issue that had to be tackled was Lithuanian - Belarusian relations.

On 20 October 1918, chancellor von Baden met with a delegation of the Council of Lithuania. During the talks he confirmed Lithuania's independence, and declared the intent to hand over administrative power to the Lithuanian government. On 11 November, Augustinas Voldemaras formed a new Lithuanian government. The parliamentary deputy Julius von Verdu du Vernoi was appointed the German diplomatic representative, Erich Zimmerl general plenipotentiary. At the end of October 1918, Germany granted the Council of Lithuania credits to the value of 110 million Marks (Homan 1918). The Lithuanian borders were to be defined in accordance with the will of its inhabitants. However, on 29 October 1918, during Voldemaras' visit to the German Ministry of Foreign Affairs it was decided that the territories which had been part of the so-called 'first German occupation' and at the time under German military administration would be handed over to Lithuania until the final decisions concerning Lithuania's borders were made at the Peace Conference. This decision concerned two territories, Lithuania and BiałystokHrodna (or Lithuania-North and Lithuania-South as the Taryba preferred to call them).

The Lithuanian government wanted its southern border to follow the Nioman River and to include the Kaunas and Viĺnia regions, Samogitia, the northern parts of the Hrodna region, and the north-eastern parts of the Suwakki region. However, Germany decided that the central part of the Hrodna region including Bielsk and Białystok counties should pass under German administration. For their part, most members of the Taryba wished the region to remain neutral territory until final adjudication at the Peace Conference. Lithuania hoped that maintaining the regions' neutral status would give Lithuania a bargaining card in its diplomatic conflict with Poland over Viĺnia (Gimžauskas 2003, 77-78, 80-85).

When Lithuania took over the administration of the territories of the 'first German occupation', the Lithuanian-Ukrainian border was defined, and the Belarusian lands were partitioned. Belarusian politicians now had to seek accommodation with Lithuania. The German decision gave the Council of Lithuania full authority 
over territories inhabited by Belarusians and which the BNR considered as part of a Belarusian state. On 22 October, the BNR's Council authorised Jan Stankievič, a member of the Belarusian Council of Vilinia, to resume talks on its behalf with the Taryba (Šupa 1998, 288). On 1 November, a delegation of the BNR handed the Lithuanian authorities a proclamation emphasising Belarusian claims to independence and repeating its territorial claims (Homan 1918). The proclamation was not well received, and only two days later, the VBR reminded the Taryba that it considered itself an organ of equal authority in the area handed to the Lithuanian administration (LCVA, f. 582, ap 2, b.1 5, 1. 5). The VBR offered Lithuania a partnership in order to obtain guarantees for the Belarusian inhabitants of the Vilinia and Hrodna regions. The VBR considered its offer to support Lithuanian statebuilding attempts as the first step in the creation of a dual Lithuanian-Belarusian state, each within its ethnic borders. However, the incorporation of the Viĺnia and Hrodna regions into Lithuania was considered a provisional option in case the Belarusian state-building project would fail and, in any case, to last for an interim period of time.

Anton Luckievič was convinced that the situation which Lithuania and Belarus found themselves in autumn 1918 was not permanent and pursued a two-track policy towards Lithuania. The BNR Premier expected that the collapse of Germany would end the German occupation and that Lithuania would lose its protector. Therefore, he estimated that the allies would make new arrangements in Eastern Europe. He therefore chose not to engage the Lithuanian government in direct talks, but rather liaised through the VBR. In November 1918, the VBR and the Taryba signed an agreement, the details of which the Belarusian side deliberately left unclear. It did not clarify whether the new state would be a dual LithuanianBelarusian entity, and the Lithuanian side did not oblige itself to purse the incorporation of all ethnic Belarusian lands. On the other hand, the Taryba treated the document as the Viĺnia and Hrodna Belarusians' acceptance of the incorporation of these lands into Lithuania. Lithuania presented the agreement on the international arena, and used its provisions to explicitly present the Belarusians as a national minority. The establishment of the Ministry for Belarusian Affairs and the inclusion of six representatives of the VBR into the Taryba were meant to confirm Lithuania's benign treatment of Belarusians.

Two days after the armistice was signed in the Compiègne Forest, Soviet Russia annulled the Brest-Litoŭsk Treaty and all subsequent agreements made with the German government. At the end of November 1918, units of the Red Army marched west and occupied Minsk. The BNR government evacuated to Viĺnia, and when the Red Army threatened that city, they moved on to Germancontrolled Hrodna. There, Luckievič appeared inactive, and did not engage either Lithuanian or German authorities. However, behind the scenes he frantically 
tried to consolidate the Belarusian movement and re-assess the political situation. He tried to avoid making any political mistakes before the peace conference. In order not to loose leverage with the allied powers, Luckievič made no moves to engage Germany. He refrained from binding declarations aimed at Lithuania or Poland. He expected that the Red Army would continue to press westward, and after a Polish-Bolshevik war (which he predicted the Bolsheviks would win), he anticipated a shift in the international balance of power (Luckievič 1991a, 168-172, Luckievič 1991b, 215-222). Thus, Luckievič kept all options open, hoping to negotiate with the winning side, and hoping to salvage the project of Belarusian statehood.

On 5 February 1919 a Polish-German agreement was signed in Białystok. It stipulated that Polish units would move into the territories being evacuated by German troops. At the same time, the BNR received a loan from the UNR, which allowed its Premier Luckievič to travel to the Versailles Peace Conference. On 22 March, a delegation led by Luckievič left Hrodna for Paris. It made a stop in Berlin, where a BNR diplomatic mission was being organised (Šupa 1998, 332). The BNR government expected that it would be difficult to continue its political activity after the Polish Army took possession of Hrodna and decided to evacuate. Some of the BNR ministers accompanied Luckievič to Berlin, while the rest of the government moved to Kaunas, which from 1919 to 1923 became the seat of the BNR Rada in exile (Rudling 2014).

\section{Conclusion}

When summarising Belarusian nationalist political activism under German occupation one should emphasise that neither the German occupying authorities, nor the imperial government in Berlin were interested in supporting the concept of an independent Belarusian state. Belarusian politicians found themselves in a difficult situation. They needed to pursue German support, but were unconvinced that this approach would be successful. They were well aware that the local people felt tied to Russia and that every move towards Germany provoked animosity. This acrimony was especially apparent in the territories which in 1915 had remained on the Russian side of the front and incorporated into land of Ober Ost only in 1918. In the territories of the so-called 'first German occupation' (Viĺnia and Hrodna provinces) German - Belarusian relations stabilised.

The German occupation facilitated a national revival in the land of Ober Ost, but the uneven development in divided Belarus limited nationalist agitation to the western part of Belarus until February 1917 (Michaluk 2009a, 93-124). Statehood was declared over a divided land, in which only a part of had been subjected to nationalist agitation. The German administration regarded Belarusian nationalism 
as a useful political commodity, an asset they supported as a counterweight to other regional nationalisms. The German administration changed how Belarusian national activists on both sides of the front viewed their reality. In the lands under German occupation from 1915, the policies of the conquerors were sympathetic to some of the aims of the nationalists. They supported a certain national mobilisation and organisation of the masses through educational and administrative measures. Reforms, such as the introduction of Belarusian education and support for the Belarusian press and culture helped improve relations. The idea of reconstituting a Belarusian-Lithuanian state formed by the Luckievič brothers collapsed as neither Germany nor Lithuania evinced interest (Michaluk 2009b, 451-66).

While the occupying authorities underwrote the cause of national activists, the arrival of German troops prompted chaos and the mass evacuation of many Orthodox residents. The Belarusian ethnographic frontier was moved further to the east, and the Belarusian component of the population decreased. As a result, nationalist agitation only reached a fraction of the intended target group. The exodus of over a million mostly Orthodox Belarusians weakened the Belarusian character of the land. In the Russian-held lands the situation was very different, and the population exposed to intense propaganda, emphasizing that Belarusians were part of the Russian nation. Belarusian nationalists were disadvantaged relative to the Lithuanian national movement, the intended state of which was located within the land of Ober Ost and the national group of which was hardly affected by the 1915 biežanstva (Turonek 1993, 20-21).

The exodus, war-time experience and propaganda had a lasting effect on Belarus. Many of the refugees' consciousness was formed by their experience. While they perceived themselves as different from the Great Russians, many refugees returned to their homeland as committed Russophiles, and continued to perceive Soviet Belarus and Russia as alternatives to the Second Polish Rzeczpospolita throughout much of the inter-war period. The idea of Belarusian independence was maintained only by small and relatively weak non-communist groups in Western Belarus (Mironowicz 2000, 11).

The nationalist activists, fighting for the control over the same area, produced their own, often incompatible national mythologies. Viĺnia was the 'spiritual home' of Belarusian nationalism and the activists' first choice for capital (Burant 1997, 646; Marples 1999, 14). Yet, Belarusian nationalism was a latecomer to the political arena, and competed against far stronger and better organised nationalist movements, who also regarded 'their' Wilno/Vilnius/Vilno/Vilne as integral to their political projects. Militarily and politically, it was under German control. The Belarusian activists' claims to Viĺnia as their capital went largely unnoticed. The declaration of Belarusian statehood in Minsk, rather than Viĺnia reflected the 
eastward shift of the centre of Belarus and confirmed the nationalists' abandonment of the krajowy idea. Furthermore, the declaration of Belarusian statehood took place outside the land of Ober Ost, in territories where nationalist agitation was very limited, and the local population were even less prepared for the activists' message of national mobilisation.

The Bolsheviks were aware of the explosive power of nationalism. Instead of attempting to undo national mobilisation, they pursued it under their own aegis. Lenin and Stalin were not opposed to the nationalists' claims of the existence of a Belarusian nation. On 1 January 1919, in accordance with Stalin's instructions, the Bolsheviks proclaimed the establishment of a Belarusian Soviet Socialist Republic in Smolensk, as a rival to the BNR and as a Soviet buffer against Poland (Selemenev 2005, 113-16). In this sense, the establishment of the BSSR appears to have been directly dependent on 25 March 1918 proclamation of the BNR, without which it seems plausible the Bolshevik leadership would have adjoined the Belarusian lands to the RSFSR (Michaluk 2010, 395-405).

Thus, Belarusian nationalism appears to have influenced Soviet decision-making. But so did the tradition of krajowość. As an echo of the krajowy idea, the Bolsheviks merged Soviet Belarus with the newly established Soviet Lithuanian republic in February, forming the equally short-lived Socialist Soviet Republic of Lithuania and Belarus, also known as LitBel, with its capital in Viĺnia (Snyder 2003, 80). As Polish forces advanced eastwards, LitBel was dissolved in the summer of 1919. After the stabilization of the Soviet-Polish border, a resurrected quasi-autonomous Soviet Belarusian republic became a founding member of the Soviet Union in 1922.

The BNR lacked not only a monopoly on physical force but also other attributes of a modern state with clearly defined and controlled borders, an army, parliament, police force, currency, constitution and codified law. In 1925, Ćvikievič admitted that the Rada of the BNR was predominantly 'of declarative nature' (Za dziaržaŭnuju niezaležnaść Bielarusi 1960, 68). His predecessor Luckievič later emphasised that the declaration was largely symbolic, and that the declaration should be seen, rather, as a statement of the will to statehood (Reznik 2002, 34). As such it had significant impact. Iosif Stalin admitted in 1924 that the national movements proved 'considerably more influential' than he had imagined before the revolution (Simon 1991, 22). Rather, the impact of the BNR lies in the fact that its proclamation was a manifestation by part of the nationalist intelligentsia that there now existed a core of nationalist believers strong enough to make a compelling case for Belarusian statehood. While Stalin himself believed in the existence of a separate Belarusian people, many leading Bolsheviks did not (Martin 2001, 395). ${ }^{25}$

25 At the tenth party congress of the VKP(b) in 1921, confronted with the statement that the Belarusian nation was an artificially cultivated figment of the imagination, Stalin responded that 'it is not true, for 


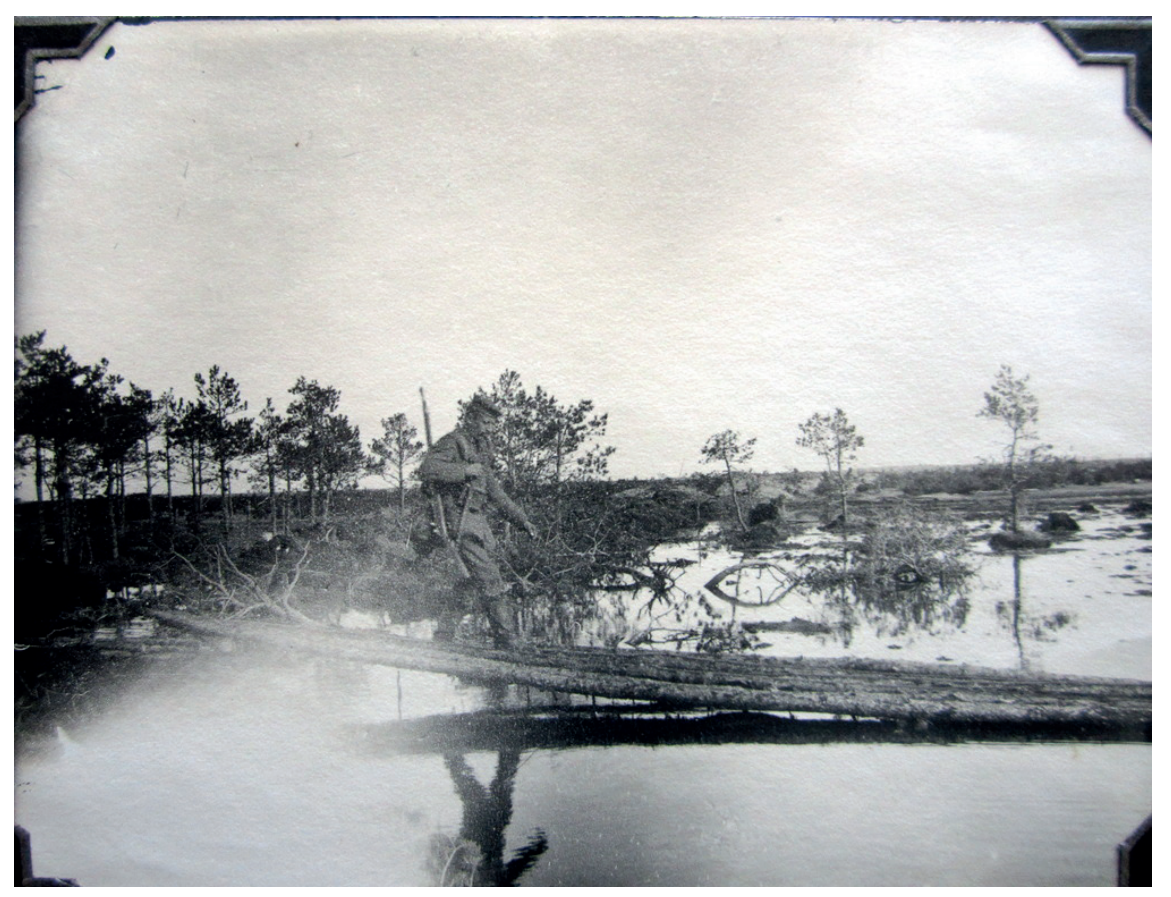

FIGURE 1: German soldier in the marshland by Baranavičy, likely 1916. From the personal photo archive of Bob Hammon. Max Jacoby, «A German doctor on the Eastern Front» Europeanan 1914-1918, «First Album of photos by Max Jacoby of the Eastern Front», image 44. Available online on http://www.europeana1914-1918.eu/en/ contributions/4205\#prettyPhoto (accessed 4 February 2014).

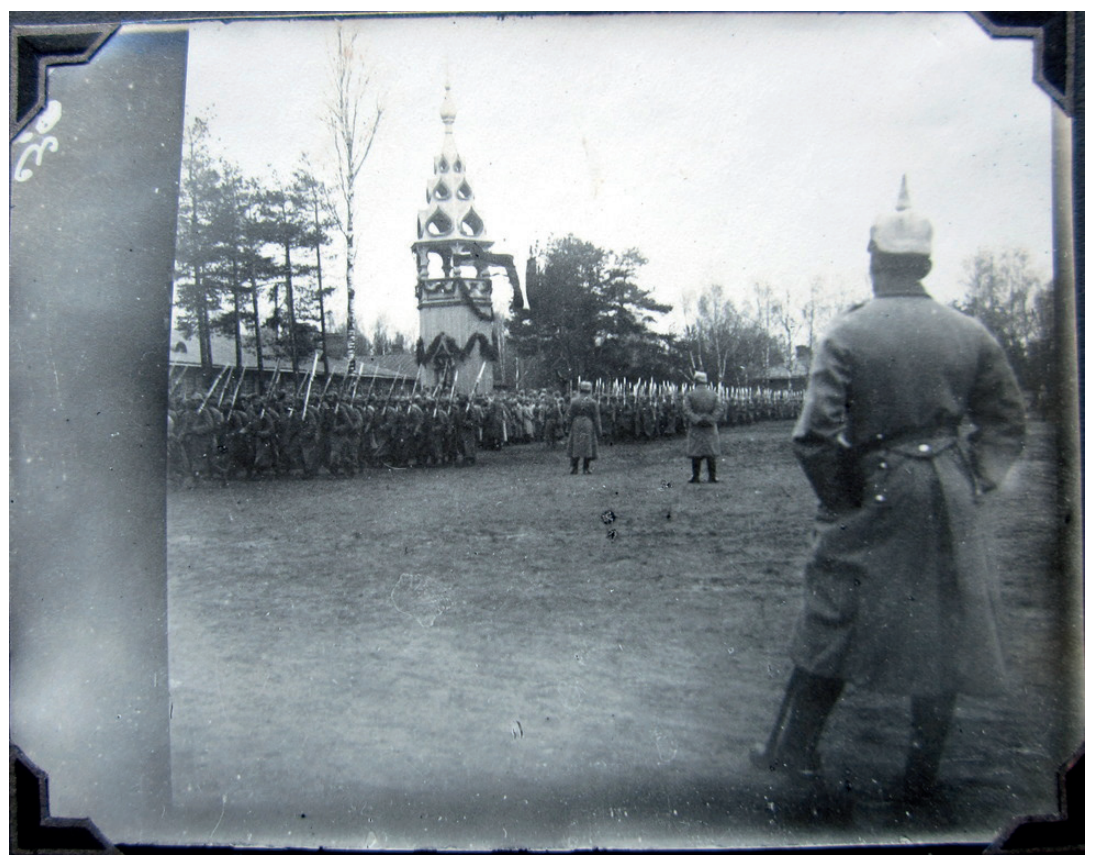

FIGURE 2: German troops parading in Baranavičy, August 1916. Photo by Max Jacoby, ibid, item 136. 


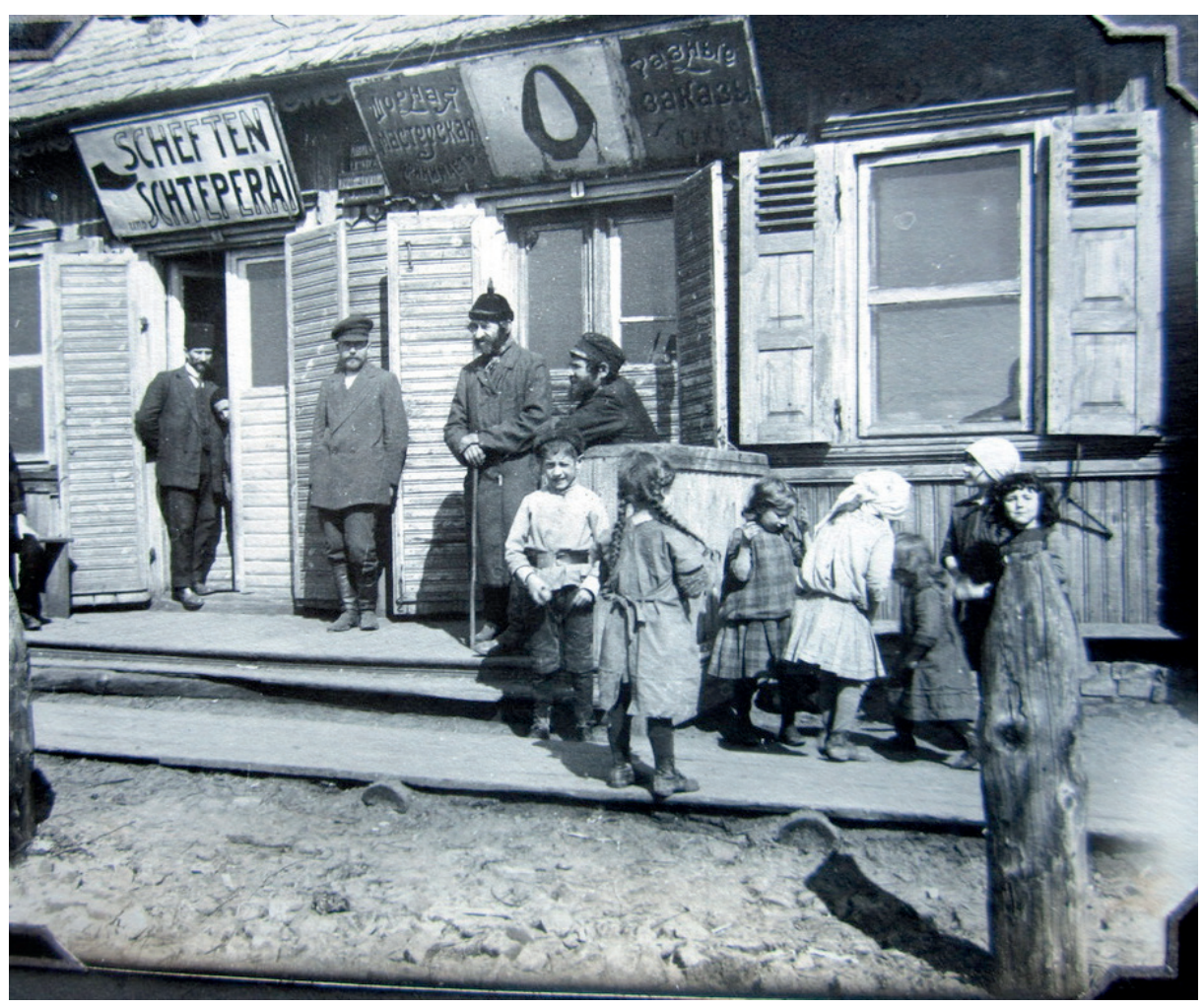

FIGURE 3: Local store in Baranavičy, 1916 or 1917. Photo by Max Jacoby, ibid, item 162.

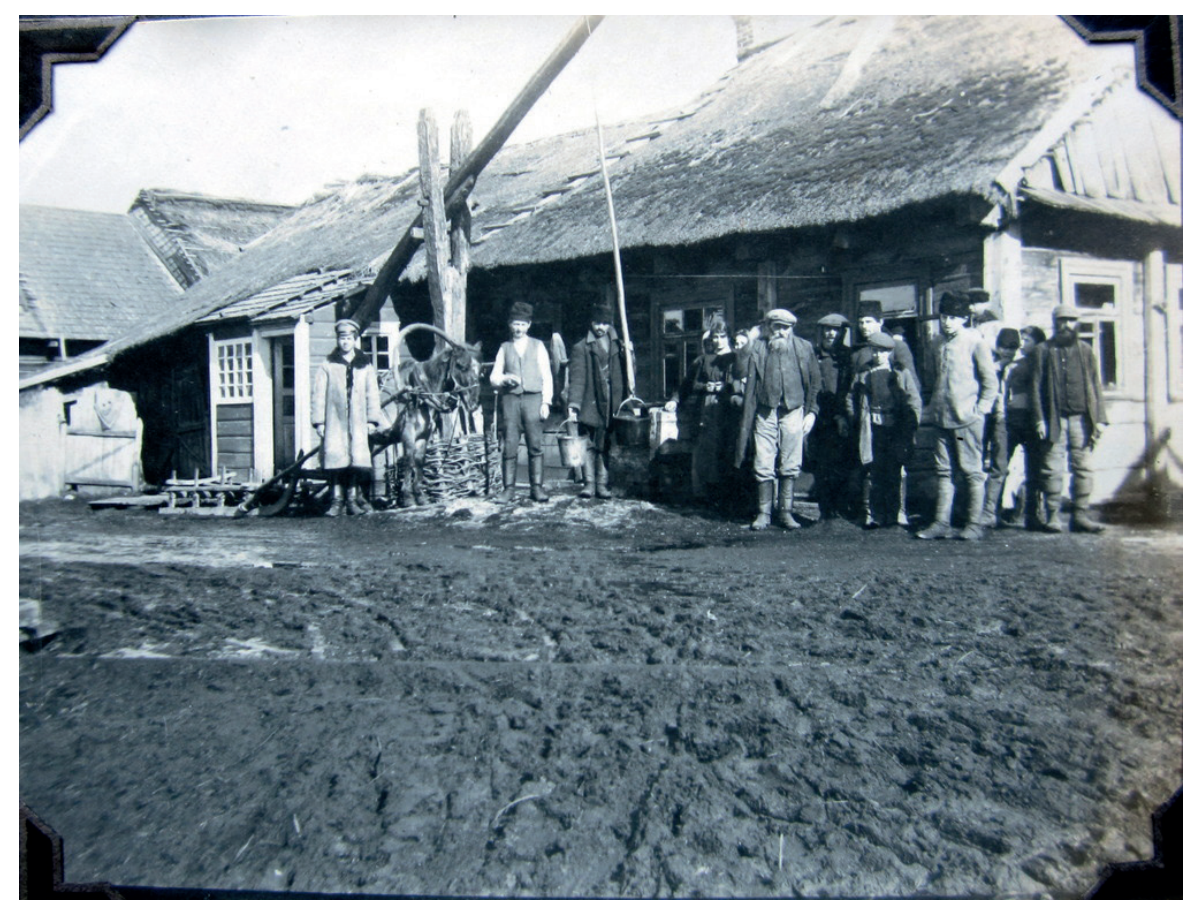

FIGURE 4: Local farm in Baranavičy, 1916 or 1917. Photo by Max Jacoby, ibid, item 164. 
In 1924, Viĺhelm Knoryn, the leader of the Belarusian Communist Party explicitly stated that it was the declaration of the BNR which convinced the Soviet leadership of the legitimacy of Belarusian claims to statehood (Mienski 1955, 18). To a growing number of Belarusian nationalists, 25 March established itself as the most important day in Belarusian history. The BNR, its state symbols and tradition were nurtured by activists in Western Belarus and in the diaspora as a counter-narrative to official Soviet history. In Lukašenka's Belarus, it retains its position as a counter-narrative to the official history writing of the current regime, and continues to exercise significant attraction on the nationalist imagination.

\section{References}

\section{Manuscripts}

Centralne Archiwum Wojskowe, (CAW), Central Military Archives, Rembertów.

Lietuvos centrinis valstybės archyvas, (LCVA), Lithuanian Central State Archives, Vilnius.

Natsional'nyi Arkhiv Respubliki Belarus', (NARB), National Archive of the Republic of Belarus, Minsk.

\section{Printed sources}

Bich, Michail, 2005. 'Hramadska-palityčnaja baraćba ŭ čas adstupleńnia revaliucyi', in V. Janoŭskaja, S. Rudovič (eds.), Historyja Bielarusi u šaści tamach: Tom 4, Bielaruś u skladzie Rasijskaj imperyi (kaniec XVIII-pačatak XX st.), Minsk: Ekaperspektyva, 2005, pp. 327-31.

Burant, Stephen, 1997. 'Belarus and the "Belarusian Irredenta" in Lithuania', Nationalities Papers, 25, 4 (December), pp. 643-58.

Chigrinov, Piotr, 2004. Istoriia Belarusi s drevnosti do nashikh dnei, Minsk: Knizhnyi dom.

Ćvikievič, Aliaksandr, 1993 [1929]. 'Zapadno-russizm: Narysy z historyi hramadzkaj myśli u XIX i pačatku XX v.', Minsk: Navuka i technika.

Dos amolike yidishe Varshe: bei der shvel fun dritn khurbn, 1914-1939, Montreal: Farband fun Varshever yidn in Montreal, 1966.

Eberhardt, Piotr, 2003. Ethnic Groups and Population Changes in TwentiethCentury Central-Eastern Europe: History, Data, and Analysis, Armonk, NY: M. E. Sharpe.

there exists a Belarusian nation, which has its own language, different from Russian. Consequently, the culture of the Belarusian people can be raised only in its native language' (Kaściuk, Ihnacienka, 1995, 117; Stalin 1953, 48-49). 
Gatrell, Peter, 1999. A Whole Empire Walking: Refugees in Russia During World War I, Bloomington, IN: Indiana University Press.

Gimžauskas, Edmundas, 1999. 'Kai kurios 1918 m. lapkričio 27 d. Lietuvių ir gudų politinio susitarimo aplinkybès (lietuvių ir gudų santykių raida 1917-1918 m.)', Lituanistica, 4, pp. 3-31.

- 2003. Baltarusiu veiksnys formuojantis lietuvos valstybei 1915-1923 m., Vilnius: Lietuvos Istorijos instituto leidykla.

Graziosi, Andrea, 2009. 'Stalin's Foreign and Domestic Policies: Dealing with the National Question in an Imperial Context, 1901-1926', paper presented at the University of Alberta, Canada, 19 November.

Hahn, Hubertus, 1995. Patriotic Culture in Russian During World War I, Ithaca: Cornell Press UP.

Herasimava, Ina, 2000. 'Ideja habrajskaj autanomii i BNR', Spadčyna, 5-6, p.32.

Heretz, Leonid, 2007. 'The "First Soviets": An Oral History of the Establishment of Stalinist Rule in Western Ukraine', paper presented at the Third Annual Danyliw Seminar, Chair of Ukrainian Studies, University of Ottawa, 13 October $<$ http:// www.ukrainianstudies.uottawa.ca/pdf/P_Heretz_Danyliw07.pdf $>$ [accessed 18 January 2014].

Homan,1918. 'Delehacyja Rady Bielaruskaj Narodnaj Respubliki da Litoŭskaj Taryby’, 88, p. 3.

Hroch, Miroslav, 2000. Social Preconditions of National Revival in Europe: A Comparative Analysis of the Social Composition of Patriotic Groups Among the Smaller European Nations. With a New Preface, New York: Columbia University Press.

Jäger, Walter, 1919. Weissruthenien: Land, Bewohner, Geschichte, Volkswirtschaft, Kultur, Dichtung. Herausgegeben von Walter Jäger, Berlin: K. Curtius.

Jezavitaŭ, Kastuś, 1993. 'Pieršy Usebielaruski Kanhres', Bielaruskaja Minuuščyna, 1, pp. 25-29.

Jurkiewicz, Jan, 1983. Rozwój polskiej myśli politycznej na Litwie i Białorusi w latach 1905-1922, Poznań: Wydawnictwo Naukowe Uniwersytetu im. Adama Mickiewicza.

Karnialiuk, Vitaĺ, 1999. 'Histaryčnaja demahrafija pieršai susvietnaj vajny: biežanstva z zachodnich huberniiau Rasiiskaj imperyi (1914-1917 hh.)', Białoruskie Zeszyty Historyczne, 12, p. 25. 
Karp, M. J., 1994. 'W poszukiwaniu współpracy między narodami byłego Wielkiego Księstwa Litewskiego podczas I wojny światowej’, in Jerzy Kłoczowski (ed.), Belarus, Lithuania, Poland, Ukraine. The Foundations of Historical and Cultural Traditions in East Central Europe. International Conference Rome, 28 April-6 May 1990, Lublin and Rome: The Institute of East Central Europe and Foundation John Paul II.

Kaściuk, Michail and Ihnacienka, Ilaryon et al (eds.), 1995. Narysy historyi Bielarusi: U 2 Ch. 2, Minsk: Bielaruś.

Katz, Dovid, 2004. Words on Fire: The Unfinished Story of Yiddish, New York: Basic Books.

Ladyseŭ, Uladzimir and Bryhadzin, Petr, 1999. Na Pieralomie Epoch: Stanaŭleńnie Bielaruskaj Dziaržaunaści (1917-1920 hh.), Minsk: BDU.

Liachoŭski, Uladzimir, 2010. Škoĺnaja adukacyja u Bielarusi padčas niamieckaj akupacyi 1915-1918 hh., Białystok and Vilnius: Bielaruskaje histaryčnaje tavarystva and Instytut bielarusistyki.

Lindner, Rainer, 1999. Historiker und Herrschaft: Nationsbildung und Geschichtspolitik in Weißrußland im 19. und 20. Jahrhundert, Munich: R. Oldenbourg Verlag.

Liulevicius, Vejas Gabriel, 2000. War Land on the Eastern Front: Culture, National Identity \& German Occupation in World War I, Cambridge: Cambridge University Press.

Lohr, Eric, 2003. Nationalizing the Russian Empire: The Campaign against Enemy Aliens during World War I, Cambridge, MA: Harvard University Press.

Luba, Vitaĺ. (ed.), 2000. Biežanstva 1915 hoda, Białystok: Prahrama rada tyžnievika Niva.

Ludendorff, Erich, 1919. Meine Kriegserinnerungen, 1914-1918, Berlin: E.S. Mittler \& Sohn, 1919.

Luckievič, Anton, 1990. 'Zlučanyja štaty ad Baltyki da Čarnaha Mora. Referat bielaruskaj delehacyi na Liežanskaj kanferencyi narodaŭ Rasiei, ustupnaje slova A. Sidarevič', Svaboda, 2, pp. 6-7

—,1991. 'Dziennik', ch. 1, Polymia, 4, pp.168-72

—, 1991. 'Dziennik', ch. 2, Polymia, 5, pp. 215-22.

Łatyszonek, Oleg, 1999. 'Krajowość i “zapadno-rusizm”: tutejszość zideologizowana', in Jan Jurkiewicz (ed.), Krajowość - tradycje zgody narodów w 
dobie nacjonalizmu, Materiały z miedzynarodowej konferencji naukowej w Instytucie Historii UAM w Poznaniu (11-12 maja 1998), Poznań: Uniwersystet im. Adama Mickiewicza.

, 1995. Białoruskie formacje wojskowe 1917-1923, Białystok: Białoruskie Towarzystwo Historyczne, 1995.

Marples, David, 1999. Belarus: A Denationalized Nation, Amsterdam: Harwood Academic Press.

Michaluk, Dorota, 2004. 'Dyplomatychni znosyny Bilorus'koi Narodnoi Respubliky ta Ukrains'koi Narodnoi Respubliky i Hetmanatu u svitli dokumentiv (berezen'- hruden' 1918 r.)', in Studii v arkhivnoi spravy ta dokumenoznavstva, t. 12, Kyiv, pp. 107-14.

_ 2007. 'Przebieg granicy między Białoruską Republika Ludową a Ukraińską Republiką Ludową w koncepcjach ukraińskich i białoruskich działaczy narodowych w latach 1918-1919 - przedstawienia kartograficzne', in Dorota Michaluk (ed.), Białoruś w XX stuleciu: W kręu kultury i polityki, Toruń: Wydawnictwo Naukowe Uniwersytetu Mikołaja Kopernika.

—, 2009a. 'Belarusskoe natsional'noe dvizhenie i Oktiabr 1917 g.', in M. Volos and A. Orekhov (ed.), Revolutsionnaia Rossiia 1917 g. i pol'skii vopros: Novye istochniki, novye vzgliady, Moscow: Institut slavianovedenie, RAN, pp. 93-124.

— 2009b. 'Przebieg białorusko-litewskiej w propozycjach działaczy BRL 1918-1919', Europa Orientalis. Studia z dziejów Europy Wschodniej i Państw Bałtyckich, t. 1, Toruń, pp. 451-66.

—_, 2010. Białoruska Republika Ludowa 1918-1920. U podstaw białoruskiej państwowości, Toruń: Wydawnictwo Naukowe Uniwersytetu Mikołaja Kopernika.

Mienski, J., 1995. 'The Establishment of the Belorussian SSR', Belarussian Review, 1, 18.

Naša Niva 1907. 'Ukrainskaja mova ŭ universytetach', November, 33, 4, p. 10.

Naumann, Friedrich, 1915. Mitteleuropa, Berlin: G. Reimer.

Niamiha, N. 1956. 'Education in the Belarussian SSR and Communist Doctrine', Belorussian Review, 3, pp. 29-101.

Pipes, Richard, 1997. Formation of the Soviet Union: Communism and Nationalism, 1917-1923. With a New Preface Cambridge, MA: Harvard University Press.

Reznik, Anatolii, 2002. K voprosu o gosudarstvennosti BNR, ili tak byla li BNR gosudarstvom?, Minsk: UP Tekhnoprint. 
Rudling, Per Anders, 2014. The Rise and Fall of Belarusian Nationalism, 19061931, Pittsburgh, PA: University of Pittsburgh Press (Forthcoming, 2014).

Rudovič, Stanislaŭ, 1999. 'Bielaruski dziejač z vialikikh panoŭ. Episody palityčnaj biahrafii Ramana Skirmunta', Histaryčny Aĺmanach, 2, pp. 20-32.

— 2001. Čas vybary: Prabliema samavyznačeńnia Bielarusi u 1917 hodzie, Minsk: Technalohija.

Selemenev, V. D. et al (eds.), 2005. 1 ianvaria 1919 goda. Vremennoe rabochekrest'ianskoe sovetskoe pravitel'stvo Belorussii: Dokumenty i materialy, Minsk: NARB.

Sidarevič, Anatoĺ, 2001. 'Suviaź niezaliežnaści i niepadzieĺnaści Bielarusi' in Encyklapiedyja historyji Bielarusi, Minsk: Bielaruskaja encyklapiedyja imia Petrusia Broŭki, vol. 6, p. 439.

Simon, Gerhard, 1991. Nationalism and Policy toward the Nationalities in the Soviet Union: From Totalitarian Dictatorship to Post-Stalinist Society, translated by Karen Forster and Oswald Forster, Boulder, CO: Westview Press.

Smaliančuk, Aliaksandr, 1999. 'Ewolucja ideologii krajowej w społecznopolitycznej działalności Ramana Skirmunta (1905-1921)', in Jan Jurkiewicz (ed.), Krajowość - tradycje zgody narodów w dobie nacjonalizmów, Poznań, pp. 114-15.

—, 2001. 'Paliaki Minščyny i bielaruski nacyjanaĺny ruch', BelarusikaAlbaruthenica, 21, pp. 171-85.

—, 2004. Pamiž krajevaściu i nacyjanaĺnaj idejaj: Poĺski ruch na bielaruskich i litoŭskich zamliach 1864-liuty 1917 g., St. Petersburg: Nevski Prostor.

Snapkoŭskaja, S. V., 1998. Adukacyjnaja palityka i škola na Bielarusi u kancy XIX - pačatku XX st., Minsk: Natsional'nyi instytut obrazovannia Respubliki Belarus'.

Snyder, Timothy, 2003. The Reconstruction of Nations: Poland, Ukraine, Lithuania, Belarus, 1569-1999, New Haven and London: Yale University Press.

Stalin, Joseph, 1953. Works, vol. V, Moscow: Foreign Languages Publishing House.

Strazhas, Abba, 1993. Deutsche Ostpolitik im Ersten Weltkrieg: der Fall Ober Ost 1915-1917, Wiesbaden: Harrasowitz.

Sukiennicki, Wiktor, 1984. East Central Europe During World War I: from Foreign Domination to National Independence, Boulder and New York: East European Monographs, Distributed by Columbia University Press.

Sushko, Georgii, 2002. 'Nemetskoe vozrozhdenie v zaporozhskom regione', in Mizhnatsional'na zlahoda: spil'ne mynule - spil'ne maibutne (problemy vshanuvan- 
nia pam 'iati zhertv trahedii etnostiv Ukrainy), Kyiv: Informatsiinyi servis.

Szpoper, Dariusz, 1999. Sukcesorzy Wielkiego Księstwa: Myśl polityczna $i$ działalność konserwatystów polskich na ziemiach litewsko-białoruskich $w$ latach 1904-1939, Gdańsk: Arche.

Šupa, Siarhiej (ed.), 1998. Archivy Bielaruskaj Narodnaj Respubliki, t. 1, ch. 1, Vilnius, New York: Belaruski instytut navuki i mastatsva, Tavarystva bielaruskaha piśmienstva, Naša Niva.

Tarasiuk, Dariusz, 2001. 'Kwestia białoruska w poglądach mińskich Polaków', Belarusika - Albaruthenica, vol. 22, pp. 186-93.

Tereshkovich, Pavel, 2004. Etnicheskaia istoriia Belarusi XIX-nachala XXvv.: V kontekste Tsentralnoi-vostochnoi Evropy, Minsk: BGU.

Törnquist-Plewa, Barbara, 2001. Vitryssland: Språk och identitet $i$ ett kulturellt gränsland, Lund: Studentlitteratur.

Turonek, Jerzy, 1993. Białoruś pod okupacja niemiecka, Warszawa: Książka i Wiedza.

Turuk, F., 1921. Beloruskoe dvizhenie: Ocherk istorii natsional'nogo $i$ revoliutsionnogo dvizheniia belarussov, Moscow, n.p.

Ulashchik, N., 1968. 'Gramotnost' v dorevoliutsionnoi Belorussii', Istoriia SSSR, 1, pp. 106-16.

Urban, Pavel, 1994. Da pytańnia etničnaj prynaliežnaści lićvinaŭ, Minsk: VTS 'Baćkaǔščyna'.

Utgof, Valentine, 2004. 'In Search of National Support: Belarusian Refugees in World War One and the People's Republic of Belarus', in Nick Baron and Peter Gatrell (eds.), Homelands: War, Population and Statehood in Eastern Europe and Russia, 1918-1924, London: Anthem Press.

Varonka, Jazep, 1920. Bielaruski ruch ad 1917 da 1920 hoda: karotki ahliad, Kaunas: A. Baka i H. Mankes.

Vogel, Walter (ed.), 1926. Schlachten des Weltkrieges. In Einzeldarstellungen bearbeitet und herausgegeben im Auftrage des Reichsarchivs. Band 9, Die Kämpfe um Baranowitschi: Sommer 1916. 2. Auflage, Oldenburg and Berlin: Gerhard Stalling.

Za dziaržaunuju niezaležnaść Bielarusi. For national independence of Byelorussia: Dakumienty i materialy sabraniia i padrukhtavan'ia publikacyji I. Kasiakom, pad kiraŭnictvam R. Astraŭskaha, 1960, London. 